\title{
Animal abuse: Profile of the offender, typology of violence and forms of control
}

\author{
Gisele Kronhardt Scheffer \\ Master in Animal Law and Society (UAB). Veterinarian. \\ Research line: Animal abuse from the perspective of Criminology \\ Leandro Ayres França \\ Post-Doctorate in Criminal Sciences. Coordinator of the Study Group on Contemporary Criminology \\ (GECC)
}

André Felipe da Silva Guedes

Post-Doctorate in Materials Engineering and Technology. Professor at Faculdade Estácio do Rio Grande do Sul - Brazil

Recommended citation. KRONHARDT SCHEFFER, G., AYRES FRANÇA, L., DA SILVA GUEDES, A.F., Animal abuse: Profile of the offender, typology of violence and forms of control, dA. Derecho Animal (Forum of Animal Law Studies) 12/1 (2021). - DOI https://doi.org/10.5565/rev/da.515

\begin{abstract}
This article aims to address animal abuse by analyzing the offender's criminological profile in terms of gender, age and social status. It also discusses the probable causes of criminal conduct against animals. It verifies, through the analysis and interpretation of data collected in a questionnaire applied to Brazilian Veterinarians, cases of animal abuse and the profile of the offender. Finally, it compiles the existing awareness measures in Brazil and in other countries and proposes solutions to the problems raised.
\end{abstract}

Keywords: animal; abuse; profile of the offender; causes of mistreatment; awareness measures.

Resumen - Malos tratos a los animales: perfil del agresor, tipología de violencia y formas de control

Este artículo tiene como objetivo abordar el maltrato animal analizando el perfil criminológico del agresor en términos de género, edad y condición social. También analiza las causas probables de la conducta delictiva contra los animales. Verifica, a través del análisis e interpretación de los datos recogidos en un cuestionario aplicado a Veterinarios brasileños, los casos de maltrato animal y el perfil del infractor. Finalmente, recopila las medidas de concienciación existentes en Brasil y en otros países y propone soluciones a los problemas planteados.

Palabras clave: animales; abuso; perfil del agresor; causas de maltrato; medidas de concienciación. 


\section{Summary}

1. Introduction

2. Methodology and sample

3. Results and discussion

4. Possible alternatives for raising awareness

5. Conclusion

6. Bibliography

\section{Introduction}

The link that unites men and animals is ancient. The domestic animal - and even the exotic one acquired, over time, the status of family member. It appears, however, that, although its importance has increased within many families, the same does not occur under the Brazilian legal system, because, for this, the animal is not yet considered a subject of rights: it only has legal protection, in an anthropocentric perspective, a statement supported by Levai ${ }^{1}$ : "The colorful protectionist prevents, so often, from seeing what is hidden behind a law supposedly committed to the welfare of the animals, because in the end what is intended to protect is the human interest."

In Brazil, Law number $9605 / 98^{2}$ equates, in its art. 32, domestic animals to wild, native or exotic animals for the purpose of applying penalties related to acts of abuse: "practicing an act of abuse, mistreatment, injuring or mutilating wild, domestic or domesticated, native or exotic animals confers to the defendant a sentence from three months to one year of prison". This Law, along with the Federal Constitution, represents the legal system that protects animals at the federal level in the country.

Regardless of an apparently protective legislation for animals, there are a large number of cases of abuse: abandonment, neglect, beatings, mutilation, burns, wild animals trafficking, zoophilia, promotion of quarrels, depletion of animal breeders due to exhaustive reproduction, illegal hunting and use of animals for recreational purposes, among others.

It is understood that certain procedures or activities considered legal from the legislation point of view should be mentioned, because lately they have generated protests and revulsion in various sectors of society: research on animals in laboratories, the slow and cruel death in slaughterhouses, the cattle fistulation ${ }^{3}$ and bullfighting. For Becker, ${ }^{4}$ "certain behaviors are considered incorrect, but no law applies to them and there is no organized system to detect those who break the informal rule". It is noteworthy, however, that Becker did not address the issue of animal abuse, and that his reflections on the Sociology of Deviance were used in this article to expand the concept of abuse beyond the legal definition.

Agnew $^{5}$ defines animal abuse as "any act that contributes to the pain or death of an animal or that threatens its welfare". This definition, according to the author, has several advantages, such as not limiting abuse only to illegal behaviors, reinforcing Becker's statement.

Unfortunately, it is clear that, despite the fact that some cases of animal abuse meet great repercussions, these crimes (and, consequently, their agents) are more leniently tolerated by legislation and society in comparison with other transgressions, clearly reinforcing the anthropocentric perspective.

It should be noted that the research in this article does not aim to analyze animal cruelty as a predecessor to violent acts practiced against human beings, despite studies - for example, the one carried out by Nassaro ${ }^{6}$ - demonstrating a close relationship between abuse of animals and people. It will be sought, then, to emphasize the importance of the criminological study of the animal abuse as a disgusting act per se, since any form of life must be valued and respected.

\footnotetext{
${ }^{1}$ LEVAI, L. Direito dos animais (Campos do Jordão 2004) 48.

${ }^{2}$ BRASIL. Law 9.605/1998 in Vade Mecum (São Paulo 2016) 1447-1454.

${ }^{3}$ Rumen fistulation: the creation of a semi-/permanent fistula between the rumen and the body wall.

${ }^{4}$ BECKER, H. Outsiders: estudos de sociologia do desvio (Rio de Janeiro 2008) 13.

${ }^{5}$ AGNEW, R. The Causes of Animal Abuse: A Social-psychological Analysis, in Theoretical Criminology. 2 (1998) 177-209.

${ }^{6}$ NASSARO, M. Aplicação da teoria do link - maus tratos contra os animais e violência contra pessoas - nas ocorrências atendidas pela Polícia Militar do Estado de São Paulo (São Paulo 2013).
} 
Criminology being "the body of knowledge about crime as a social phenomenon", and that "includes in its scope the process of making laws, violating laws and reacting to the breaking of laws"', this article has as its theme the criminological aspects of animal abuse, delimited to the profile of the offender, the causes of these conducts and the possible solutions to the problem of mistreatment from a criminological point of view.

The problems raised are the following: What is the profile of the offender? What causes a person to mistreat animals? What are the possible solutions to the problem of animal abuse?

The work seeks to achieve the following objectives: analyzing the profile of the offender as an object of study in Criminology, raising the causes of criminal conduct against animals and pointing out possible solutions to the issue of animal abuse.

The methodology used can be classified as exploratory-descriptive research; all the information presented is based on studies already published on the theme of this article and on the data collected in a questionnaire given to Veterinarians who work in the city of Porto Alegre and Metropolitan Region, in the state of Rio Grande do Sul, Brazil.

To achieve the aforementioned objectives, the article is structured as follows: first, the research methodology and sample are indicated; afterwards, the results obtained through the data collection instrument are presented and the discussion is carried out, in which the profile of the agents of abuse against animals (gender, age and socioeconomic status) is analyzed, as well as the causes that lead to the commission of such acts; finally, possible alternatives of sensitization and awareness are addressed, in which a new criminological perspective is defended for the analysis of this problem, as well as the realization of post-humanist (4th dimension) rights for non-human animals. It should be noted that after the references there is the Appendix, containing the model of the data collection instrument applied to the interviewees.

\section{Methodology and sample}

In relation to the research methodology, a data collection instrument was applied to approximately 2,800 Veterinarians who work in the city of Porto Alegre and the Metropolitan Region, because "as one of the few people likely to interact with an abused animal, the Veterinarian is in a privileged position to witness and identify animal cruelty". 8

Questionnaire was the chosen method, whose questions were elaborated by the researchers according to the specific objectives of the work. They were made available on the internet through the Google Forms tool during the months of March and April 2017. When the questionnaires returned to the researchers, there was no possibility of identifying the interviewees, thus ensuring absolute confidentiality.

The data collection instrument contained fifteen questions, distributed as follows: fourteen closed questions, of simple or multiple choice, in which, in five of them, there was the possibility of adding, by the interviewee, some alternative not contemplated in the question. The last question was open, dedicated to the opinion or testimony - optional - of the interviewee.

Questions 01 and 02 dealt with the time and place of work of the Veterinarian (urban, rural or both). The questions numbered from 03 to 07 aimed to verify the number of cases of abuse, the place where they were treated (clinic/hospital, NGO, Zoonosis Center, slaughterhouses or others), the situation of the animal (stray, domiciled, for slaughter) and if the animal was wild, domiciled wild, exotic, domiciled exotic, domestic or domesticated. Question 08 sought to classify cases of aggression towards animals. Questions 09 to 12 addressed the profile of the offender in relation to the age group, gender and type of abuse, while question 13 aimed to identify the possible causes of abuse. In question 14, the interviewee's legal procedure regarding the cases of abuse was investigated. Finally, question 15 was presented, already addressed in the previous paragraph. If, perhaps, the interviewee had not dealt with cases of abuse, they would be directed from question 03 to question 15 .

To carry out the pilot project, 25 questionnaires were sent with the objective of verifying the understanding, on the part of the interviewees, of the questions elaborated by the researchers, 14 of which were returned. Analyzing the answers from the pilot project questionnaires, necessary adjustments were made. It should be noted that the pilot project questionnaires were not incorporated into the total sample.

Until the end of April 2017, 280 completed questionnaires returned to the researchers, exceeding the necessary number of samples for the research, estimated at 271. After the collection was completed, the collected data were tabulated, and the respective analysis was made. The results and discussion will be demonstrated below.

\footnotetext{
${ }^{7}$ SUTHERLAND, E. - CRESSEY, D. Principles of Criminology (Philadelphia 1960) 3.

${ }^{8}$ BENETATO, M. - REISMAN, R. - MCCOBB, E. The Veterinarian's role in Animal Cruelty Cases, in Journal of the American Veterinary Medical Association. 238 (Jan. 2011) 33.

8 Derecho Animal. Forum of Animal Law Studies, vol. 12/1
} 


\section{Results and discussion}

From the answers obtained through the application of the questionnaires to the Veterinarians, it was possible to tabulate the data through graphs, as well as proceed with the analysis of the collected information. It is noteworthy that graphs were used as they allow a better visualization and interpretation of the results.

\subsection{Results}

In question 01, it was asked: "How long have you been in the profession?". Graph 1 shows that the majority of respondents $(46.9 \%)$ have been working for more than 10 years as Veterinarians. 23.5\% of Veterinarians responded from 06 to 10 years, while $20.9 \%$ said they have been working between 01 and 05 years. Finally, only $8.7 \%$ responded that they have been working in the profession for less than a year.

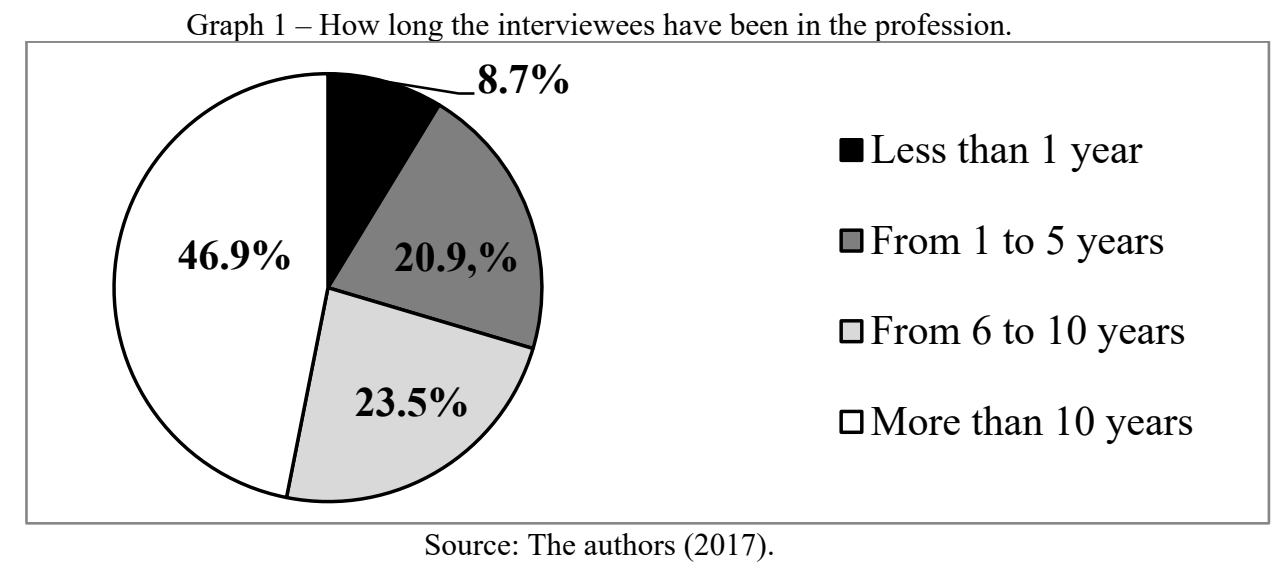

Question 02 referred to the interviewee's area of activity (urban, rural or both). Most respondents $(60.9 \%)$ said they work in the urban area. $34.4 \%$ of Veterinarians answered "in urban and rural areas". Only $4.7 \%$ work in the rural area, as can be seen in Graph 2.

Graph 2 - Interviewees' area of activity.

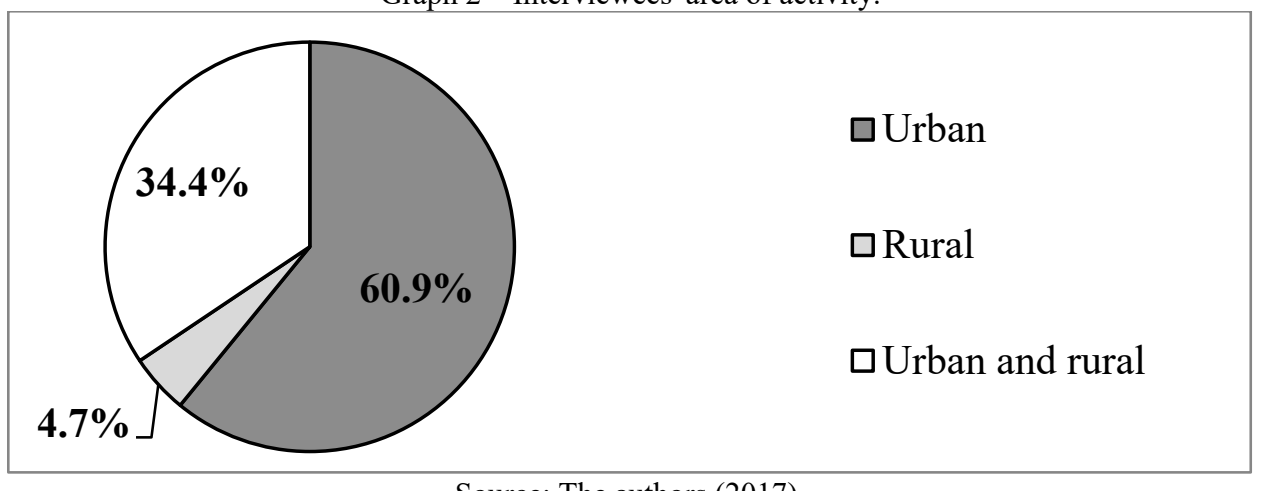

Source: The authors (2017).

In continuation of the tabulation of the collected data, the answers given to the following question can be seen in Graph 3: "Have you attended to situations of animal abuse?" It is clear that the vast majority of respondents $(77.5 \%)$ have already attended to this type of occurrence. It should be noted that $22.5 \%$ of the respondents were sent, from this point on, directly to question 15 , as they had not dealt with situations of animal abuse. 


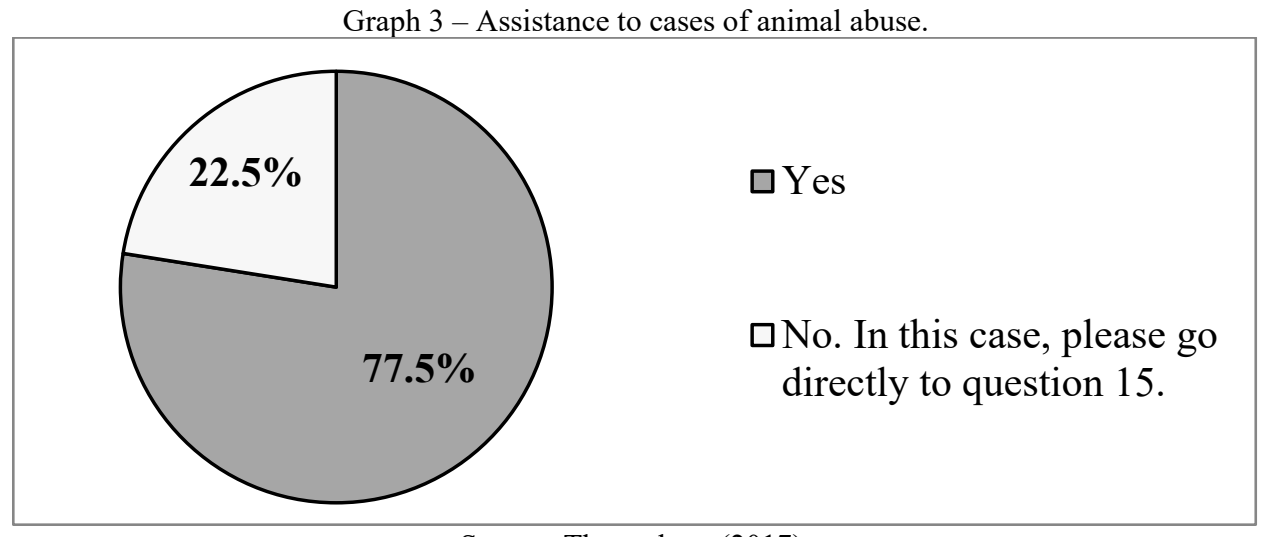

Source: The authors (2017).

The next question, number 04, dealt with the number of cases of abuse that the Veterinarians have attended. The alternative "more than 20 " was indicated by $38.3 \%$ of the respondents. $29.9 \%$ answered "from 01 to 05 ", while $19.6 \%$ marked "from 06 to 10 " and $12.1 \%$ said they had already attended "from 11 to 20 cases" (Graph 4).

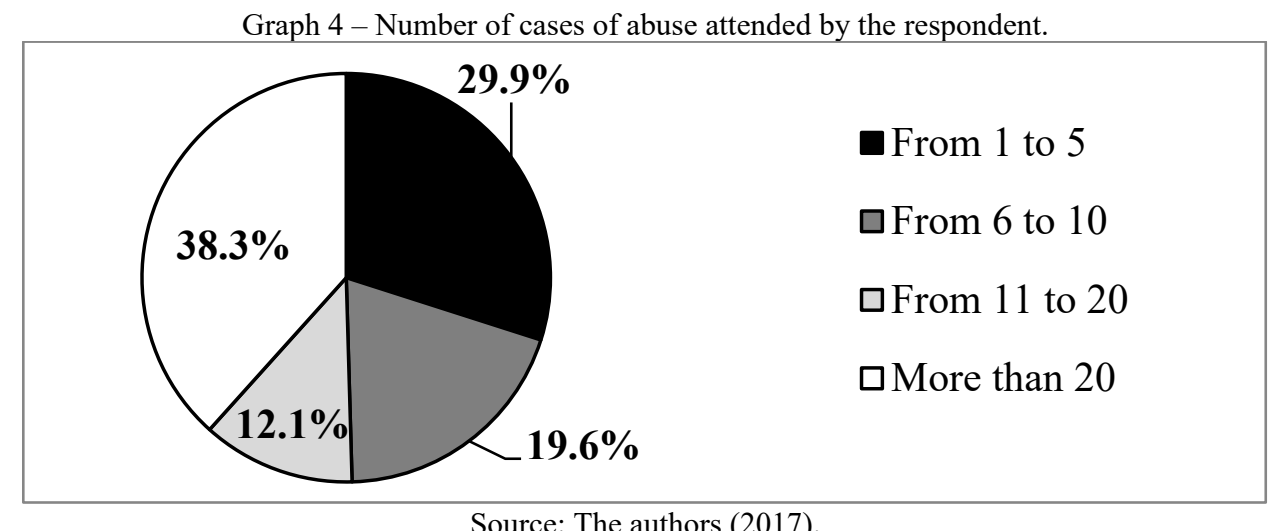

Following up on the questions, the interviewees were asked about the place of work in which the greatest number of cases of abuse were seen. The options were: "Clinic/Hospital"; "NGO"; "Zoonosis Center"; "Slaughterhouses"; and "other". The "Clinic/Hospital" option represented the majority of answers, with $62.1 \%$; the "NGO" option received $11.2 \%$ of the responses, while "Slaughterhouses", $6.1 \%$, and "Zoonosis Center", 5.6\% (Graph 5).

Graph 5 - Work place where the greatest number of cases of abuse were attended to.

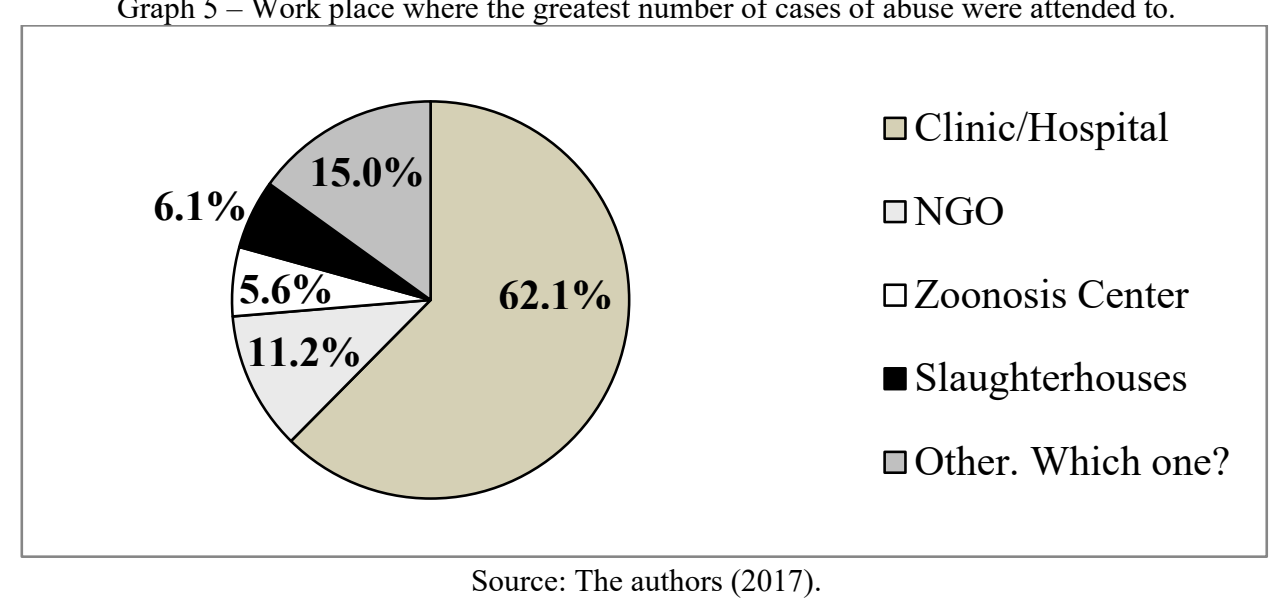

$15.0 \%$ of the interviewees expressed their opinion as "other". Here are some of the testimonies: "dairy 
cooperative"; "zoo"; "sanitary surveillance"; "hoarders"; "Inspection of crimes with fauna involved"; "Agricultural inspection"; "Home care"; "Experimental dairy cattle farm"; "rural extension"; "Wild Animal Screening Center (CETAS)"; "Porto Alegre City Hall - Special Secretariat for Animal Rights"; "Health Surveillance"; "Farms"; "Autonomous Veterinarian"; among others.

It can be seen, from the statements above, that the Veterinarian faces cases of abuse in variety of work places.

Question 6, on the other hand, sought to verify the predominant origin of animal abuse victims treated by the interviewees. The "domiciled" option was selected by $56.3 \%$ of respondents. The option "stray" was checked by $37.7 \%$, while "animals for slaughter" was mentioned by $6.0 \%$ of the interviewees, according to Graph 6.

Graph 6 - Predominant origin of abused animals.

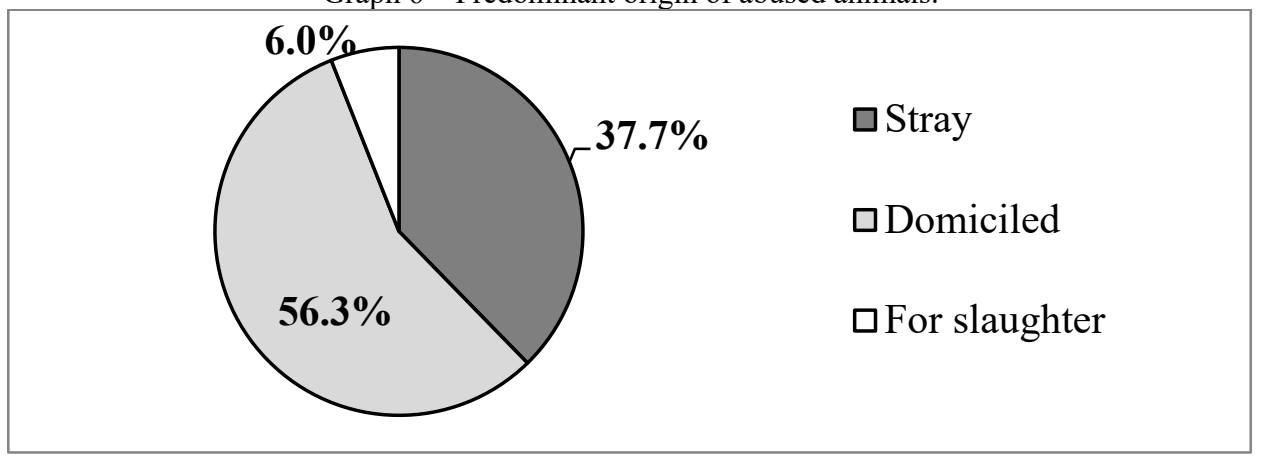

Source: The authors (2017).

Question 7, in turn, addressed the predominant classification of animal abuse victims treated by the respondent. Most of them (81.3\%) indicated the option "domestic", followed by "domesticated", which obtained $15.0 \%$ of the answers. The other options, "wild", "domiciled wild" and "exotic" 9 were mentioned, respectively, by $1.9 \%, 1.4 \%$ and $0.5 \%$ of the interviewees. The option "domiciled exotic" was not selected (Graph 7).

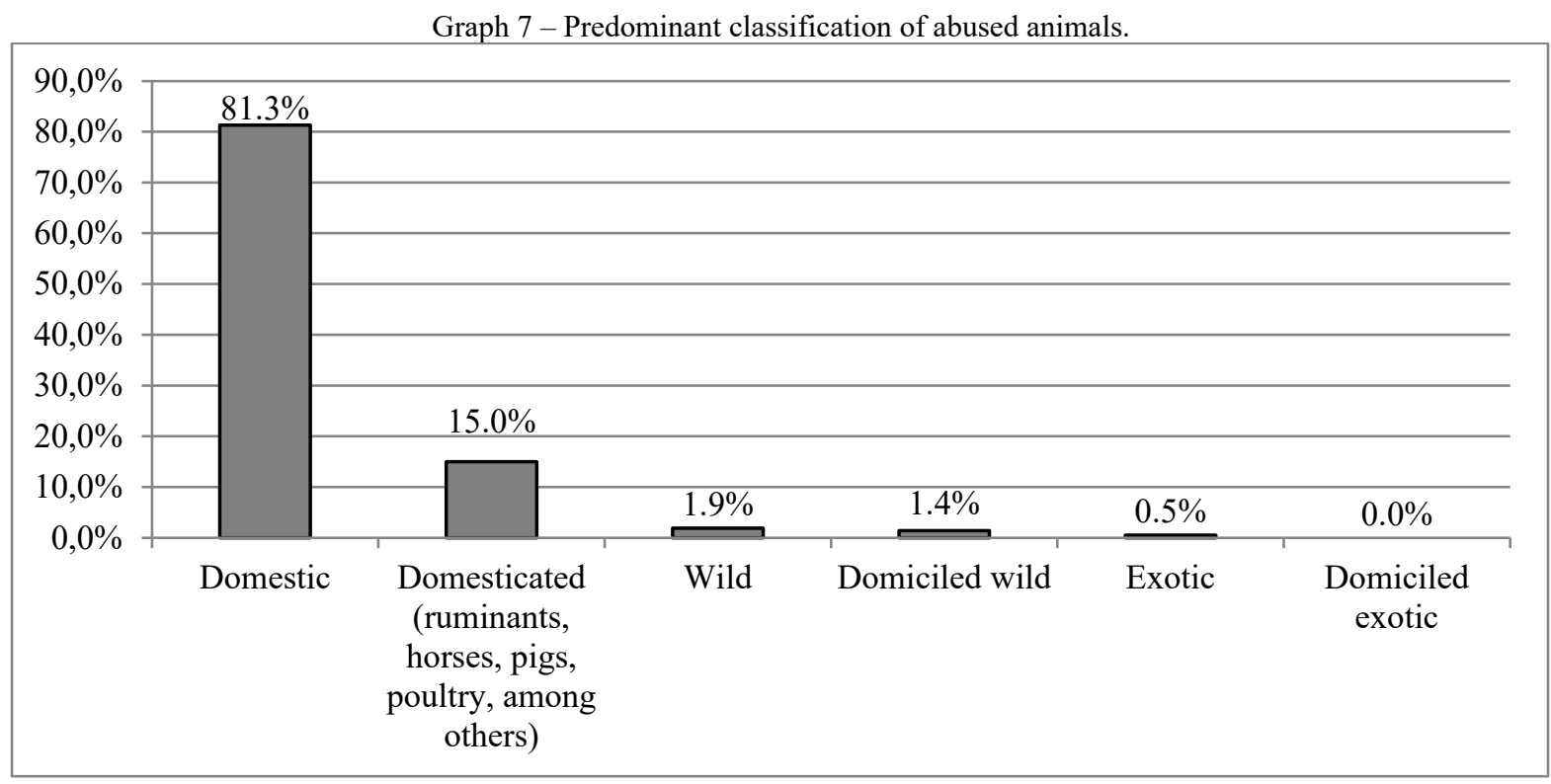

Source: The authors (2017).

\footnotetext{
${ }^{9}$ Domestic animals are those that live or are raised at home, in the company of human beings. Examples: dogs and cats. Domesticated animals are those whose nature is not to live at home, but which have been domesticated to maintain the behavior of a domestic animal. Examples: horses, chickens, cows. Exotic animals are those that are introduced into a geographic region accidentally or intentionally by humans. Examples: piton, ferret, elephant, lion, cockatoo. Wild animals are those free-living natives that live all or part of them in the country of origin or in its waters.
} 
The next question, number 8 , aimed to classify the most numerous cases of abuse seen by the interviewees. More than one option could be selected. 215 responses were obtained. The most frequent cases of abuse were: "beatings", with $63.3 \%$; "Deprivation of veterinary care", with $62.8 \%$; "Animal hoarding", with $49.3 \%$; "Deprivation of water and food", with $48.8 \%$; and "confinement/chaining", with $45.1 \%$. All alternatives of the question, shown in decreasing order of occurrence, can be seen in Chart 1.

Chart 1 - Classification of the most numerous cases of abuse attended.

\begin{tabular}{|l|l|}
\hline Beatings & $63.3 \%$ \\
\hline Deprivation of veterinary care & $62.8 \%$ \\
\hline Animal hoarding & $49.3 \%$ \\
\hline Deprivation of water and food & $48.8 \%$ \\
\hline Confinement / chaining & $45.1 \%$ \\
\hline Poisoning & $42.8 \%$ \\
\hline Weapon wounds (firearms or melee weapons) & $34.4 \%$ \\
\hline Burns & $28.8 \%$ \\
\hline Forced and continuous breeding & $28.4 \%$ \\
\hline Rape & $18.6 \%$ \\
\hline Injured draft animals & $14.0 \%$ \\
\hline Quarrels or competitions & $12.6 \%$ \\
\hline Use in religious or "black magic" rituals & $7.0 \%$ \\
\hline Hanging / choking & $6.0 \%$ \\
\hline Others, which ones? & $5.6 \%$ \\
\hline
\end{tabular}

Source: The authors (2017).

In this question, the option "others" was also offered, checked by $5.6 \%$ of the interviewees. The following are some of the testimonials:

- "verbal abuse and humiliation, psychological torture, animals left locked in cars, continuous bathing for exhibitions, continuous attendance at exhibitions, overuse of medications and supplements, punishments for wrong behavior";

- "problems in stunning before the slaughter";

- "animal with muscle torsion due to lack of bath and grooming, where the knots locked the animal's paw, and the animal couldn't move";

- "the majority of animals from rescue by clandestine kennel animal protectors. I attended a patient who was taken out of a cemetery where a black magic ritual had been performed";

- "abandonment";

- "apart from quarrels and religious rituals, all the rest";

- "psychological abandonment, tutors financing the maintenance of geriatric animals or terminals in hotels or hospitals, but without any further contact or exchange of affection. They receive veterinary assistance, but aren't loved by their tutors. For me this is the highest current rate of abuse I experience, followed by the lack of veterinary assistance even when the tutor is alerted to the need for care".

As for questions 9 to 12, they aimed to verify the profile of the animal abuser. If, perhaps, the interviewee was unaware of the authorship of the abuse, he should go directly to question 13 . Some interviewees commented on the subject:

- "the agent of abuse was the company that raised the animals";

- "hoarders are usually women alone of the female sec [sex] and are the ones I have the most direct contact with";

- "all types, from tutors unable to own animals, young people who think they are playing to protectors who hoard animals";

- "hoarders: predominant age is over 40 years. Owners of animals with low-income: predominant age is between 20 and 40 years";

- "I don't know, because they are animals that come to me after being rescued by an NGO". 
The purpose of question 9 was to verify the age range of the agent of abuse. The question was answered by 164 respondents, meaning that, many times, the authorship of the abuses was unknown by the Veterinarian. "Between 20 and 40 years old" was the alternative indicated by $61.6 \%$, representing the majority of responses; "Over 40 years old" was checked by $33.5 \%$ of those questioned. The alternative "between 10 and 20 years old" was mentioned by $3.7 \%$ of the interviewees, while "under 10 years old" obtained the percentage of $1.2 \%$. These data can be seen in Graph 8.

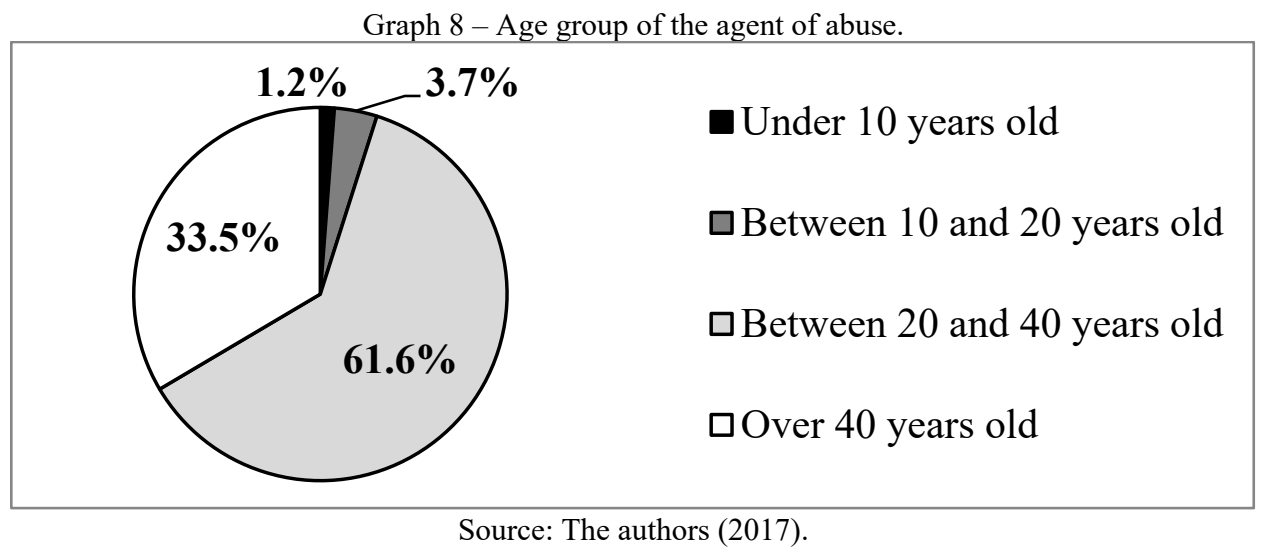

Still aiming to establish a profile of the agent of animal abuse, question 10 asked whether the interviewee was aware of the aggressor's gender. Among the 163 interviewees who identified the agent, a vast majority of $85.3 \%$ selected "male". The "female" alternative was checked by $14.7 \%$ of respondents (Graph 9).

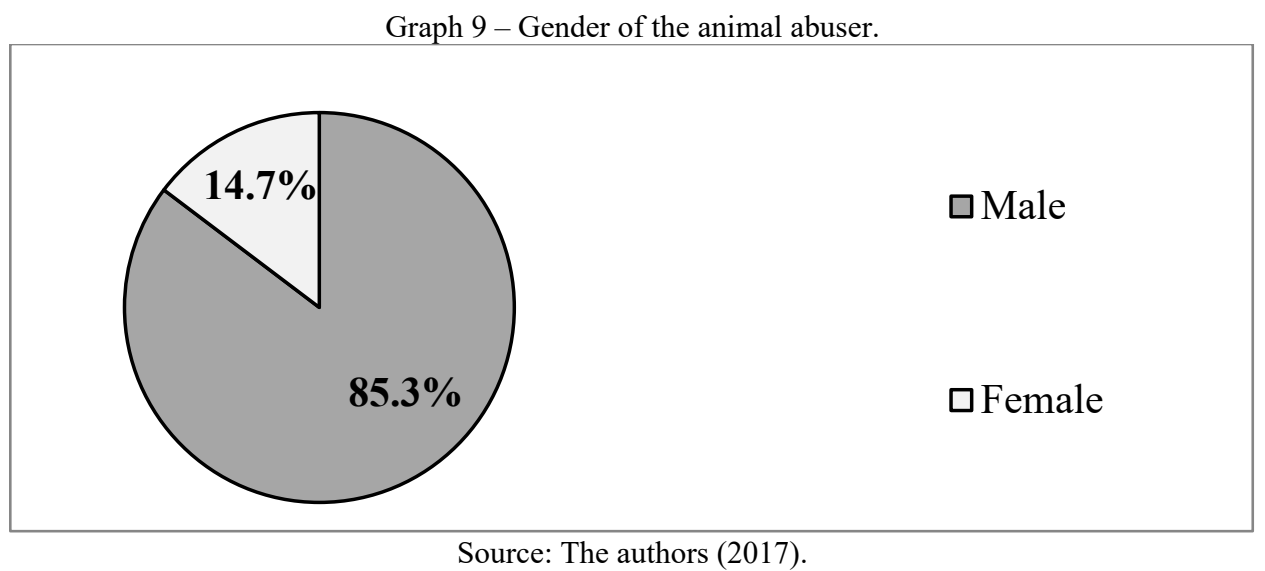

Question 11, in turn, sought to investigate the situations of abuse when the interviewee identified that the agents belonged to the male gender, and more than one of the alternatives presented could be checked. 156 responses were obtained. The most frequent cases of abuse, in decreasing order, were: "beatings", with $66.7 \%$; "Deprivation of veterinary care", with $46.2 \%$; "Weapon wounds (firearms or melee)", with 36.5\%; "Deprivation of water and food", with 33.3\%; "Confinement/chaining", with 32.7\%; "Poisoning", with $28.2 \%$; "Rape", with 25.0\%; "Burns", with 19.9\%; "Injured draft animals", with $16.0 \%$; "Quarrels or competitions", with 15.4\%; "Forced and continuous breeding", with 14.1\%; "Animal hoarding", with $11.5 \%$; "Hanging/choking", with 7.1\%; and "use in religious rituals", with 3.8\%.

In this question, the option "others" was also offered, checked by $0.6 \%$ of the interviewees. Following, a statement:

- "I do not work at hospitals and emergencies so cases of direct violence do not come to me, but I hear this type of testimony from the clients' mouth. They say the offenders are men of all ages, young people from the poor class who torture (hanging, stabbing, kicking) stray animals or neighbors bothered by noise (the animals are shot with a BB gun)". 
The next question, number 12, sought to identify situations of abuse when the interviewee identified that the agents belonged to the female gender. The researchers received 134 responses and, in the same way as the previous question, more than one of the alternatives presented could be checked. The most frequent cases of abuse, in decreasing order, were: "animal hoarding", with $64.2 \%$; "deprivation of veterinary care", with $61.9 \%$; "deprivation of water and food", with $41.0 \%$; "Confinement/chaining", with $40.3 \%$; "Forced and continuous breeding", with 26.1\%; "Poisoning", with 23.1\%; "Beating", with 19.4\%; "Burns", with 9.0\%; "Use in religious rituals", with 5.2\%; "Injured draft animals", with $2.2 \%$; "Hanging/choking", "Weapon wound (fire or melee)" and "quarrels or competitions", with $0.7 \%$ each. The alternative "rape" was not selected by the interviewees. The option "others" was checked by $1.5 \%$ of the interviewees, who said: "lack of environmental and individual hygiene", "don't know any female abuser", "mainly animal hoarding and deprivation of veterinary care".

As much as the answers indicate an equitable distribution of some behaviors, it is important to show that, in case of abuse committed by males, the interviewees answered that, generally, they were situations of physical aggression (commissive behaviors). On the other hand, the cases seen by the professionals as being authored by females revealed a significant percentage of situations of negligence (omissive behaviors). The graph below compiles the proportional percentage of occurrences of abuse comparatively between male and female agents, in decreasing order of episodes involving the male gender and, conversely, in ascending order involving the female gender.

Graph 10 - Proportional percentage of occurrences of abuse comparatively between male and female agents.

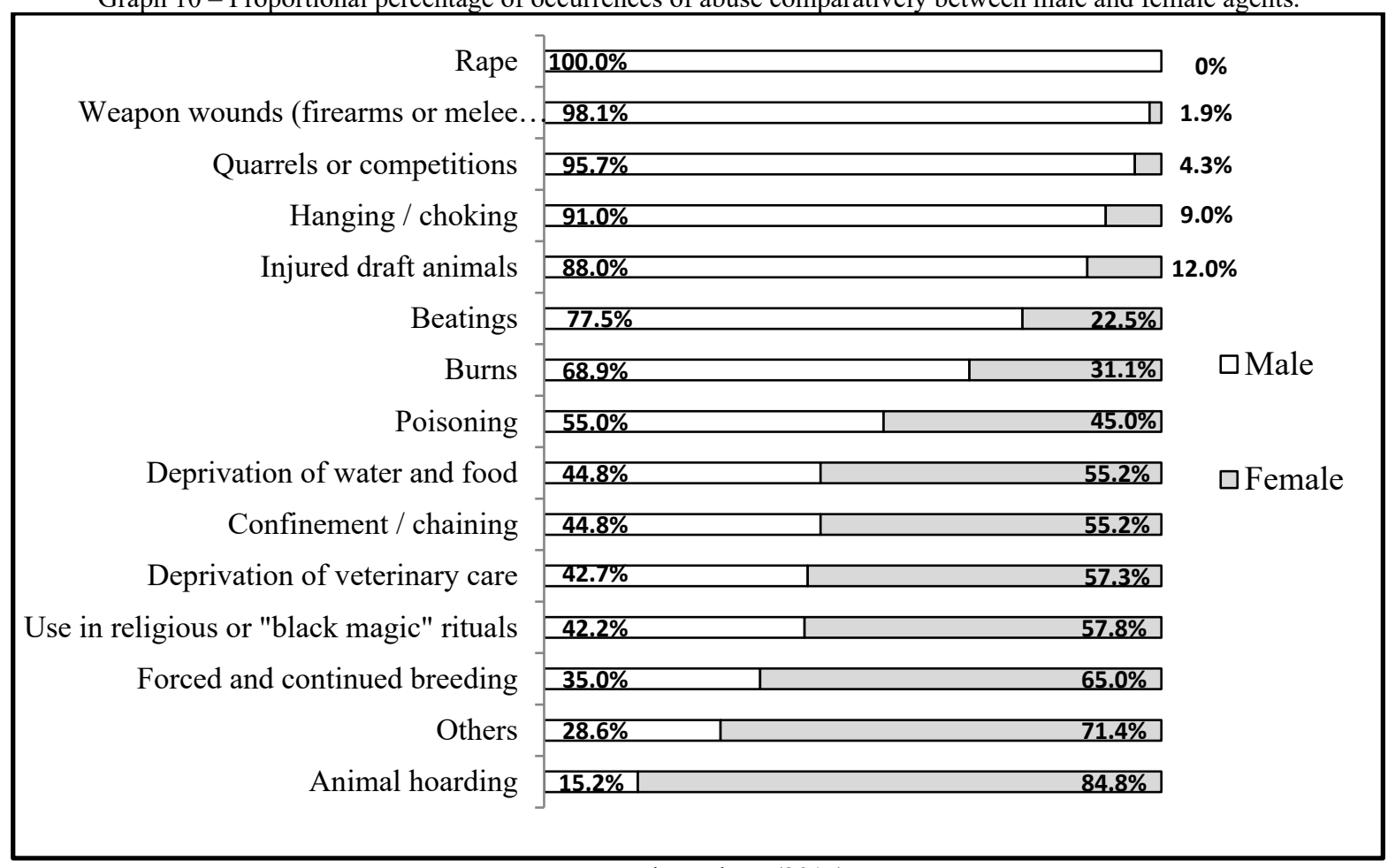

Source: The authors (2017).

Regarding the causes of abuse, question 13 asked whether interviewee knew the reasons that led the agent to attack the animal, and they could check one or more of the alternatives offered. This question was answered by 204 Veterinarians. The option "negligence or ignorance about the welfare of the animal" was pointed out by $69.6 \%$ of the interviewees; "The animal was disobedient" received $28.4 \%$; "The animal bit or threatened the offender or a family member" was checked by $20.1 \%$; "The animal belonged to an enemy of the offender" was reported by $19.1 \%$ of respondents, while "The offender was an alcoholic or addicted to drugs" received $16.2 \%$; "Family fight" was mentioned by $13.7 \%$, and finally, $9.8 \%$ of the interviewees pointed out "the author suffers from mental disorder". However, $26.5 \%$ of the respondents claimed to be unaware of the reasons that led the agent to attack the animal (Chart 2).

Chart 2 - Classification of the most numerous cases of abuse.

\begin{tabular}{|l|r|}
\hline Negligence or ignorance about the welfare of the animal & $69.6 \%$ \\
\hline The animal was disobedient & $28.4 \%$ \\
\hline
\end{tabular}




\begin{tabular}{|l|c|}
\hline I don't know the reasons & $26.5 \%$ \\
\hline The animal bit or threatened the offender or a family member & $20.1 \%$ \\
\hline The animal belonged to an enemy of the offender & $19.1 \%$ \\
\hline The offender was an alcoholic or addicted to drugs & $16.2 \%$ \\
\hline Family fight & $13.7 \%$ \\
\hline The author suffers from mental disorder & $9.8 \%$ \\
\hline Other. Which one? & $8.8 \%$ \\
\hline
\end{tabular}

Source: The authors (2017).

Among the interviewees who pointed out different reasons from those presented in the options $(8.8 \%)$, the most relevant testimonies for the objective of the research were selected:

- "risk to his bird breeding or fear [thereof] (in the case of hawks, opossums, etc.)";

- "together with negligence and ignorance in relation to welfare, cases in which the person does not have physical, financial conditions, interest or a proper space, and voluntarily or not accepted animals from children, parents, relatives or third parties...";

- "bad financial situation";

- "animal brought to the clinic for other unrelated complaints (diseases) not related, in the client's view, with abuse";

- "not wanting to spend money on the animal, using the animal as a source of profit, evil, animal phobia";

- "hoarders usually hit animals to separate fights";

- "wanted to take revenge on his wife and beat her pet".

As a last closed question, question 14 aimed to ascertain whether the Veterinarians reported the cases of animal abuse they treated. 214 responses were obtained. The option "No" was indicated by $51.9 \%$ of the interviewees. The option "Yes, but I don't know the outcome of the cases" was chosen by $20.1 \%$ of the respondents. $15.4 \%$ answered "Yes, but there was no action in relation to the cases" and $12.6 \%$ stated "Yes, and measures have been taken by the competent departments", as can be seen in Graph 11 .

Graph 11 - Did the interviewee report the cases of abuse?

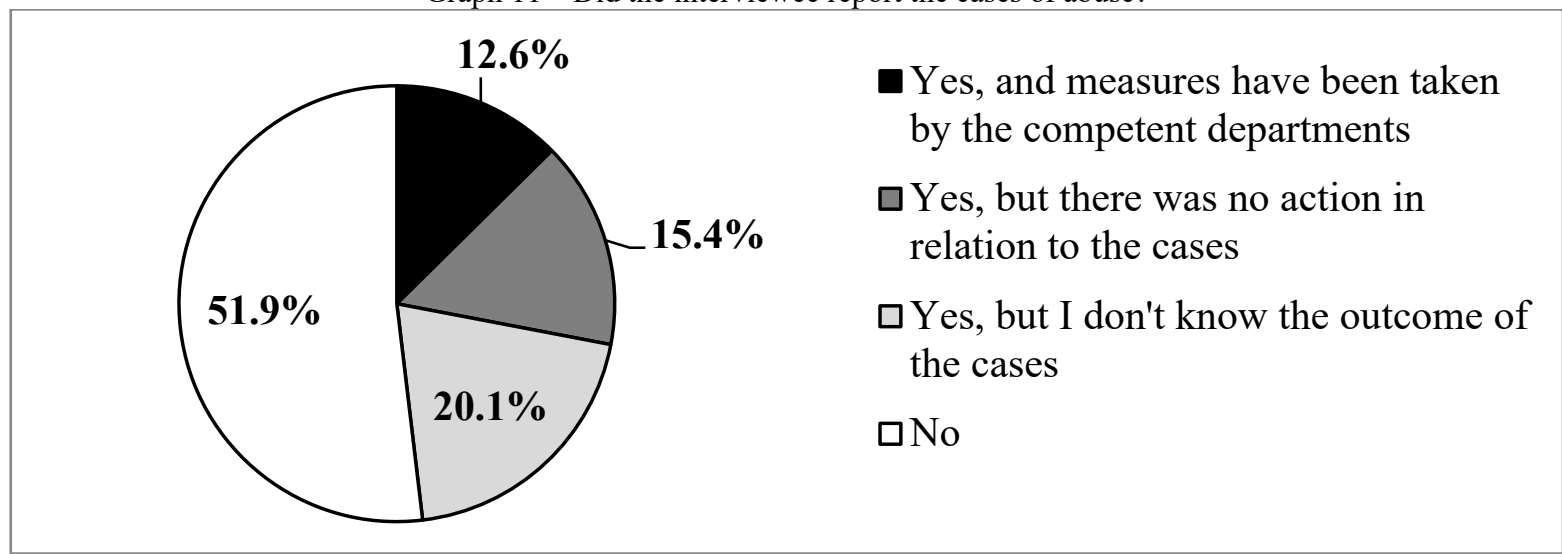

Source: The authors (2017).

At the end of the data collection instrument, an open question was presented, number 15 , in case the interviewee wished to make some observations or give a testimony about situations of mistreatment, types of violence, animal and agent profiles, consequences of cases or other subjects. Of the 82 testimonials, some were highlighted:

- "most of the cases of abuse that occur in my life were brought to me by animal protectors, and these animals were often stolen from guardians. Protectors who work in regions of extreme poverty most of the time";

- "all the cases I saw came from people with low income"; 
- "quite common to assist people who have domestic animals, but without financial conditions to keep the animal, they end up taking it to the vet belatedly, when diseases were aggravated by time...";

- "because it is a humble place, people think that animals should always be trapped, and that discipline is achieved with violence. But the most frequent case is deprivation of vaccines and veterinary care, which is only done when the animal has been suffering for a long time";

- "carter horses";

- "most of the animals I attended were very old and due to poor nutrition and the effort made by traction they ended up with spinal injuries which caused the owners to abandon these animals. I believe that the problem lies in the possibility that our laws give any individual the right to have an animal wherever they want, eating the way that the person chooses and using it without respecting any limits. The responsibility for having a horse should be much greater than having a car";

- "note that the aggressors are exclusively low-income and have poor education".

It is verified, therefore, through the responses and testimonies of the interviewees, that there is ample scope for discussion, since the data obtained proved to be very useful in identifying the profile of the aggressor and the causes of the animal abuse, two of the objectives of this research.

\subsection{Discussion}

Before starting the discussion of the data, correlations were made between the responses obtained through the collection instruments. It is worth mentioning that, for reasons of editorial extension, only the correlations that address the objectives proposed by this article, that is, those related to the profile of the offender and the causes of abuse, will be presented here.

When proceeding to the correlation between questions 2 (interviewees' area of activity) and 9 (age group of the offender), eight instruments were disregarded for not having the area of activity or the age group of the offender checked. The following results were then obtained from the 156 valid instruments:

- among the veterinarians who work in urban area, 90 of them identified the age group of the agent of animal abuse. The following was found: under 10 years old, $2.2 \%$; between 10 and 20 years, $4.4 \%$; between 20 and 40 years old, $64.4 \%$; over 40 years old, $28.9 \%$.

- among the veterinarians who work in rural areas, four of them identified the age group of the abuser. The data obtained were as follows: under 10 years old, $0 \%$; between 10 and 20 years old, $0 \%$; between 20 and 40 years old, $25.0 \%$; over 40 years, $75.0 \%$.

- among the veterinarians who work in urban and rural areas, 62 of them identified the age group of the animal abuser. The following was verified: below 10 years old, $0 \%$; between 10 and 20 years, $3.2 \%$; between 20 and 40 years old, $59.7 \%$; over 40 years, $37.1 \%$.

Analyzing the data, it can be seen that the predominant age group of the abuser is "between 20 and 40 years" in urban and urban and rural areas, corroborating what was stated by Flynn. ${ }^{10}$ Arluke and Luke ${ }^{11}$ also found this age group to be prevalent among the offenders. The authors conducted a study in Massachusetts, United States of America and concluded, with regard to the age of the offenders that were prosecuted, that the majority of the abusers, despite the ages varying from nine to 83 years old, were around 30 years old. In the research conducted by Arluke and Luke, teenagers represented $27.0 \%$ of the agents.

For Gullone and Clarke, ${ }^{12}$ the apex of committing acts of abuse against animals is in the 18 to 25 age group and tends to decrease steadily, a fact that confirms Graham and McNeill's Theory of Desistance. According to Graham and McNeil, ${ }^{13}$ "fundamentally, desistance refers to the definitive cessation of the offending behavior". Desistance can be conceptualized as being "a dynamic process of human development - which is situated and deeply affected by their social contexts - in which people move away from aggressive behavior and towards compliance with social and legal norms". ${ }^{14}$

\footnotetext{
${ }^{10}$ FLYNN, C. A Sociological Analysis of Animal Abuse in The International Handbook of Animal Abuse and Cruelty: Theory, Research, and Application (West Lafayette 2008) 155-174.

${ }^{11}$ ARLUKE, A. - LUKE, C. Physical Cruelty toward Animals in Massachusetts, 1975-1996, in Society and Animals. 5 (1997) 195204.

12 GULlONE, E. - CLARKE, J. Animal Abuse, Cruelty, and Welfare: An Australian Perspective in The International Handbook of Animal Abuse and Cruelty: Theory, Research, and Application (West Lafayette 2008) 305-334.

${ }^{13}$ GRAHAM, H. - MCNEILL, F. Desistência: prevendo futuros in Criminologias alternativas (Porto Alegre 2017). 574.

${ }^{14}$ MCNEILL (2016) apud GRAHAM, MCNEILL (2017) 575.

16 Derecho Animal. Forum of Animal Law Studies, vol. 12/1
} 
The "over 40 years" age group was the most noted by veterinarians working in rural areas $(75.0 \%)$. One of the hypotheses is that, in recent decades, rural populations counted on older people due to the migration of young people to urban areas, a fact confirmed by Maia and Buainain ${ }^{15}$ : "As a consequence of selective migration in rural areas, with the predominant flow of more educated and female youths, the aging process and the masculinization of the rural population have been intensifying".

When correlating questions 2 (interviewees' area of activity) and 10 (gender of the abuser), three instruments were disregarded because the interviewees did not mark the area of activity and results were obtained from the 161 valid instruments.

Among the veterinarians who work in urban areas, 93 of them identified the gender of the abuser. The following was found: male $(80.6 \%)$ and female $(19.4 \%)$.

Among the veterinarians who work in rural areas, five of them identified the gender of the animal abuser. The male gender was checked by $75.0 \%$ of respondents, while $25.0 \%$ marked the female gender.

Among the veterinarians who work in urban and rural areas, 63 of them identified the gender of the offender. The "male" option obtained $93.7 \%$ of the responses, and "female", $6.3 \%$.

Analyzing the correlation between the interviewee's area of activity and the gender of the offender, it was found that in all areas the male gender predominates. Adams ${ }^{16}$ argues that mistreatment of animals is part of dominance and exploitation by men over other less powerful beings - women, children and animals. In this perspective, patriarchy has led men to use violence as a means of control over other individuals, including animals.

In our anthropocentric society, humans enjoy having absolute power over other animals. It is obvious that animal abusers, typically men, are physically bigger and stronger than their non-human victims. ${ }^{17}$

The next correlation was carried out between questions 2 (interviewees' area of activity) and 11 (situations of abuse caused by male agents), where three instruments were disregarded for not having the area of activity checked.

Among the veterinarians who work in urban areas, 88 of them identified situations of abuse caused by male agents. The three cases of mistreatment by male agents most frequently reported by professionals in this area were: beatings (70.4\%), deprivation of veterinary care $(52.3 \%)$ and weapon wounds $(40.9 \%)$.

Among the veterinarians who work in rural areas, three of them identified cases of abuse caused by male agents. Beatings (66.7\%), deprivation of veterinary care $(33.3 \%)$ and rape $(33.3 \%)$ were the options mentioned. It is worth remembering that the interviewee could indicate more than one option.

Among the veterinarians who work in urban and rural areas, 62 of them identified cases of abuse caused by male agents. The most highlighted options were: beatings $(61.3 \%)$, deprivation of veterinary care (38.7\%) and deprivation of water and food $(35.5 \%)$.

Continuing the analysis, in the correlation between questions 2 (area of activity of the interviewees) and 12 (situations of abuse caused by female agents), three instruments were disregarded for not having the area of activity checked.

Among the veterinarians who work in urban areas, 86 of them identified situations of abuse caused by female agents. The three situations of abuse by female agents most frequently reported by professionals in this area were: deprivation of veterinary care $(67.4 \%)$, animal hoarding $(65.1 \%)$ and deprivation of water and food $(36.0 \%)$.

Among the veterinarians who work in rural areas, two of them identified cases of abuse caused by female agents. The following was found: animal hoarding (50.0\%) and forced and continuous breeding $(50.0 \%)$.

Among the veterinarians who work in urban and rural areas, 43 of them identified situations of abuse caused by female agents. The most checked alternatives were: animal hoarding (60.5\%), deprivation of veterinary care $(53.5 \%)$ and deprivation of water and food $(53.5 \%)$.

Analyzing the data mentioned above, it can be inferred that the acts committed by the male gender generally refer to an action (rape, beatings, use of weapons, for example), while the acts committed by the female gender generally refer to an omission (deprivation of water and food, deprivation of veterinary care and animal hoarding), data that reinforce Adams' patriarchal theory. ${ }^{18}$

As regards animal hoarding, Ryder ${ }^{19}$ states that it can be considered an act of unintentional cruelty

\footnotetext{
15 MAIA, A. - BUAINAIN, A. O novo mapa da população rural brasileira in Confins. 25 (2015). Web Page: https://confins.revues.org/10548?lang=pt [last visited: May 23, 2019].

16 ADAMS, C. Woman-battering and Harm to Animals, in Animals and Women: Feminist Theoretical Explorations (Durham, NC 1995) 55-84.

${ }^{17}$ FLYNN, supra note 10.

${ }^{18}$ ADAMS, supra note 16.

${ }^{19}$ RYDER, R. Speciesism, Painism and Happiness: A Morality for the Twenty-first Century (Exeter, UK 2011).
} 
performed by individuals affected by psychological disorders and/or mental suffering. Steketee et al., ${ }^{20}$ when analyzing North American animal hoarders, found histories of trauma during childhood and/or adulthood, absence or neglect of parents and difficulty in maintaining relationships. Hoarders believe that by rescuing these animals, they are guaranteeing their welfare, which would not be achieved on the streets. However, the excessive number of animals in inappropriate places shows the inability to guarantee their basic needs for survival.

Patronek $^{21}$ and the Hoarding of Animals Research Consortium (HARC) ${ }^{22}$ conducted research on hoarders and found that the first compulsive signs of hoarding animals are identified when the person is middle aged. Patronek found that $76.0 \%$ of hoarders were female, aged between 37 and 60 years; $72.2 \%$ were single, widowed or divorced; $55.6 \%$ live alone; and owned, on average, 39 animals. The profile of the hoarders, verified by the HARC study, can be summarized as follows: $83.1 \%$ belonged to the female gender, with an average age of 55 years for women and 53 for men; $71.8 \%$ were single, widowed or divorced; $46.5 \%$ lived alone; $54.9 \%$ were unemployed, retired or disabled; and they had, on average, 50 animals (women) and 47 animals (men). In some situations, there was a relationship of abuse from, and neglect by, family members.

Comparing the two studies above with the results found by the researchers, there are similarities, since women represented most animal hoarders. In addition, data from the Patronek and HARC surveys is also confirmed by the following testimonies that were collected during the research: "hoarders are usually women who live alone and are the ones that I have the most direct contact with"; "Hoarders: predominant age is over 40"; "I worked for a long time with animal hoarders in Porto Alegre. [...] mistreatment is mostly caused by deprivation of veterinary care, confinement in a degrading situation (poor hygiene, overcrowding and the presence of ectoparasites) [...]".

As for the correlation between questions 2 (interviewees' area of activity) and 13 (reasons that led the offender(s) to attack the animal), three instruments were disregarded for not having the area of activity checked.

Among the veterinarians who work in the urban area, 126 of them identified the reasons that led the offender(s) to attack the animal. The three most highlighted alternatives were: negligence or ignorance in relation to the welfare of the animal $(69.8 \%)$, the animal was "disobedient" $(27.8 \%)$ and the animal bit or threatened the offender or a family member $(19.0 \%)$.

Among the veterinarians who work in rural areas, five of them identified the reasons that led the offender(s) to attack the animal: neglect or ignorance regarding the welfare of the animal $(60.0 \%)$, the animal was "disobedient" $(20.0 \%)$ and the animal belonged to an enemy of the offender $(20.0 \%)$ were the most checked options.

Among the Veterinarians who work in urban and rural areas, 70 of them identified the reasons that led the offender(s) to attack the animal. The following was found: negligence or ignorance in relation to the welfare of the animal (71.4\%); the animal was "disobedient" (31.4\%); the animal belonged to an enemy of the offender and the animal bit or threatened the offender or a family member, with the same percentage $(22.8 \%)$.

Solot, ${ }^{23}$ in addressing neglect as the biggest reason for abuse, interviewed Doug Trowbridge, coordinator of field studies at the American Humane Association (AHA). According to Trowbridge, 90.0\% of abuse is attributed to negligence - often caused by ignorance -, citing as examples the guardians of dogs that leave them unsheltered on a cold night and others who tether the animal and forget to replace the water in its bowl.

For Arkow and Munro, ${ }^{24}$ neglect means failure to provide the basic physical and/or emotional needs of life, for example, food, water, shelter, veterinary care, companionship and affection. Abandoning an animal is an obvious example of neglect. Letting a leash tighten around a puppy's neck is another.

\footnotetext{
${ }^{20}$ STEKETEE, G. et al. Characteristics and Antecedents of People who Hoard Animals: An Exploratory Comparative Interview Study in Review of General Psychology 15 (2011) 114-124.

${ }^{21}$ PATRONEK, G. Hoarding of Animals: An Under-recognized Public health Problem in a Difficult-to-study Population in Public Health Reports. 1 (1999) 81-87. Web Page: https://www.ncbi.nlm.nih.gov/pmc/articles/PMC1308348/pdf/pubhealthrep000290083.pdf [last visited: May 23, 2019].

22 HARC. Health Implications of Animal Hoarding in Health \& Social Work. 27 (May 2002) 125-136. Web Page: http://search.proquest.com/docview/210548261?pq-origsite=qscholar [last visited: May 23, 2019].

23 SOLOT, D. Untangling the Animal Abuse web in Society and Animals. 5 (1997) 257-265. Web Page: http://www.animalsandsociety.org/wp-content/uploads/2015/10/solot.pdf [last visited: May 27, 2019].

${ }^{24}$ ARKOW, P. - MUNRO, H. The Veterinary Profession's Roles in Recognizing and Preventing Family Violence: The Experiences of the Human Medicine Field and the Development of Diagnostic Indicators of Non-accidental-injury, in The International Handbook of Animal Abuse and Cruelty: Theory, Research, and Application (West Lafayette 2008) 31-58.
}

18 Derecho Animal. Forum of Animal Law Studies, vol. 12/1 
Regarding socioeconomic status, Flynn ${ }^{25}$ states that, like other forms of violence, animal abuse occurs at all socioeconomic levels. However, it reinforces that the lower the socioeconomic status, the more abuses that occur against children, wives and animals.

Delabary ${ }^{26}$ validates Flynn's ${ }^{27}$ statement, and observes that, in Brazil:

the poverty of a large part of the population causes damage to animals. The situation of poverty experienced by many families in the country means that outdated practices are still used by low-income people. A striking example is the indiscriminate use of horses for work within large centers. In many situations, carters use these animals cruelly, working all day without water or food as if they were real machines. It is even sadder to see that many minors are inserted in this reality, learning to work with parents who pass on not only the teachings about work, but also the idea that the horse exists only to be exploited and does not deserve respect or attention. Complaints to the Municipal Guardianship Council may minimize this situation, because in addition to causing suffering to animals it is characterized as child labor.

Delabary continues to address poverty as one of the causes of animal abuse, focusing on the situation of dogs and cats, who suffer from a lack of food and minimal living conditions. The author assures, however, that "even if people's quality of life improves, nothing will have a complete effect without an educational action that highlights the importance and benefits of coexistence between animals and men". ${ }^{28}$

By analyzing the data that were collected, it appears that, despite the proximity that unites men and animals, the cases of abuse are very numerous and diverse and educational actions are essential. Next, possible measures to raise awareness that will help solving the problem of animal abuse will be listed.

\section{Possible alternatives for raising awareness}

Through the testimonies of the veterinarians that were interviewed, it was found that ignorance and low socioeconomic status are two of the factors that lead people to abuse animals. Living with animals can provide human beings with unconditional friendship and love, affection, loyalty and company. However, many people do not realize that leaving an animal chained under the scorching sun or depriving a bird of flying, confining it in a tiny cage, are also considered abuse.

Among other things, awareness is lacking. Therefore, "the idea that animals deserve respect must be passed on from the first years of life. If a person does not like animals, he is not obliged to take care of them and take them home, but he needs to know that he is forbidden to mistreat them and that he can be punished if he does that". ${ }^{29}$

And the author continues, stating that it is necessary to carry out continuous work within communities, "so that animals are no longer seen as objects. Therefore, education becomes the main tool to end this sad reality, since through the teachings you can work on awareness". 30

Among the various possible solutions to prevent animal abuse, it seems more recommended to develop prevention and guidance works. ${ }^{31}$ The individual, when witnessing or even attacking animals, gradually loses sensitivity to the suffering of these living beings. Therefore, the development of a critical conscience is necessary from the first stages of human life. In this way, children can become multipliers of the notion of respect for all living beings. ${ }^{32}$

Environmental education is, therefore, how the speciesist and anthropocentric line will be broken, as well as any action of domination over the other. ${ }^{33}$ According to Beirne, ${ }^{34}$ "in Criminology [...] aggression against animals has little or no sui generis significance, presumably because it is not seen as a real crime, but

\footnotetext{
${ }^{25}$ FLYNN, C. Understanding Animal Abuse (New York 2012). Kindle Edition.

${ }^{26}$ DELABARY, B. Aspectos que influenciam os maus tratos contra animais no meio urbano in Revista Eletrônica em Gestão, Educação e Tecnologia Ambiental. 5 (2012) 837-838. Web Page: https://periodicos.ufsm.br/reget/article/viewFile/4245/2813 [last visited: March 10, 2019].

${ }^{27}$ FLYNN, supra note 25.

${ }^{28}$ DELABARY, supra note 26 , at 838 .

${ }^{29}$ DELABARY, supra note 26 , at 838 .

${ }^{30} \mathrm{Id}$. at 835 .

${ }^{31} I d .$.

32 BERETTA, D. - OLIVEIRA, J. - VILELA, D. A extensão universitária e a ludicidade na educação infantil contra a crueldade animal e violência interpessoal in Revista Brasileira de Extensão Universitária. 7 (jul./dez. 2016) 139-144.

${ }^{33}$ BRÜGGER, P. Educação ou adestramento ambiental? (Chapecó; Florianópolis 2004) 165.

${ }^{34}$ BEIRNE, P. Animal Rights, Animal Abuse and Green Criminology in Issues in Green Criminology: Confronting Harms Against Environments, Humanity and other Animals (Abingdon 2013) 62.
} 
instead as a small offense against property". It is necessary, therefore, to abandon anthropological thinking short-sighted as to the true relationship between human beings and the environment - and to adopt an environmental ethical stance.

It is then possible to defend the development of biocentric criminologies for the analysis of violence against animals:

Paul W. Taylor's biocentric ethics, presented in his book, Respect for Nature, can be a guide to questioning the enslaving ethics and justice of non-human animals and natural ecosystems. [...] Every animal and plant, in Taylor's biocentric conception, has an inherent value, as it has its own good that no one should destroy. All forms of interference by which the animal or plant loses the conditions of a good life, healthy development, self-development and practical autonomy, are considered as impeding the life of these beings. [...] To interfere in the natural state of life of animals and plants to benefit human interests, is to deny them freedom to live the kind of life in which they were born, and to enjoy the inherent good of that condition. ${ }^{35}$

Felipe $^{36}$ also points out that from the biocentric ethical perspective "animals and plants can be considered as subjects of moral rights, at least in general terms. This is the right to preserve and protect their own good and the welfare of their lives". And Taylor goes further: he states that, based on this generic right, specific rights for plants and animals can be established. ${ }^{37}$ There is an urgent need to create a normative treatment for animals, through which the anthropocentric paradigm can be surpassed and the post-humanist (or fourth dimension) rights can be accomplished, admitting the legal dignity of animals as sentient beings and holders of fundamental rights.

\section{Conclusion}

At the end of the research it is concluded that, despite the proximity between men and animals, there are countless cases of abuse that still occur. In the name of anthropocentrism, the human being is entitled to decide about the fate of other beings.

Through the data collected, it is verified that the profile of the animal abuser in the researched region is the individual of the male gender, aged between 20 and 40 years, with the exception of hoarders, where the female gender predominates. It is also found that the social status of families affects the animal and the main cause of abuse is negligence or ignorance in relation to the welfare of the animal.

Socially, since animals are less valued than humans, they are not always seen as worthy of moral consideration. Legally, animals are considered property and this status makes them easy targets of abuse. Humans determine the laws and rules regarding the treatment given to other beings, and, since animals cannot speak for themselves, only submission to humans remains.

It is believed that the three proposed research problems were answered, which addressed the profile of the offender, the causes of the abuse and the indication of possible solutions to the problem.

Despite insufficient studies on the subject in Brazil, it was possible to achieve the proposed objectives, through the work of researchers from other countries and data collection from veterinarians.

It appears that the most effective way for the cycle of abuse to be avoided and no longer reproduced is education, with the consequent awareness of respect for life in all its forms.

It is possible to change the sad picture of cruelty to animals. But much remains to be done. The research that was carried out is considered extremely relevant, due to the uniqueness of the topic, but there is a long way to go until human beings leave anthropocentric and speciesist thinking behind. Such abandonment is essential for animals to be seen not as things, but as beings that must be respected as subjects of rights.

\section{Bibliography}

- ADAMS, C. Woman-battering and Harm to Animals, in Animals and Women: Feminist Theoretical Explorations (Durham, NC 1995) 55-84.

- AGNEW, R. The Causes of Animal Abuse: A Social-psychological Analysis, in Theoretical Criminology. 2 (1998) 177-209.

\footnotetext{
${ }^{35}$ FELIPE, S. Antropocentrismo, sencientismo e biocentrismo: perspectivas éticas abolicionistas, bem-estaristas e conservadoras e o estatuto de animais não-humanos in Páginas de Filosofia. 1 (2009) 16-18. Web Page: https://www.metodista.br/revistas/revistasims/index.php/PF/article/view/864/1168 [last visited: 12 fev. 2019].

${ }^{36} I d$. at 27.

${ }^{37} \mathrm{Id}$.

20 Derecho Animal. Forum of Animal Law Studies, vol. 12/1
} 
- ARKOW, P. - MUNRO, H. The Veterinary Profession's Roles in Recognizing and Preventing Family Violence: The Experiences of the Human Medicine Field and the Development of Diagnostic Indicators of Non-accidental-injury, in The International Handbook of Animal Abuse and Cruelty: Theory, Research, and Application (West Lafayette 2008) 31-58.

- ARLUKE, A. - LUKE, C. Physical Cruelty toward Animals in Massachusetts, 1975-1996, in Society and Animals. 5 (1997) 195-204.

- BECKER, H. Outsiders: estudos de sociologia do desvio (Rio de Janeiro 2008) 13.

- BEIRNE, P. Animal Rights, Animal Abuse and Green Criminology in Issues in Green Criminology: Confronting Harms Against Environments, Humanity and other Animals (Abingdon 2013) 55-86.

- BENETATO, M. - REISMAN, R. - MCCOBB, E. The Veterinarian's role in Animal Cruelty Cases, in Journal of the American Veterinary Medical Association. 238 (Jan. 2011) 31-34.

- BERETTA, D. - OLIVEIRA, J. - VILELA, D. A extensão universitária e a ludicidade na educação infantil contra a crueldade animal e violência interpessoal in Revista Brasileira de Extensão Universitária. 7 (jul./dez. 2016) 139-144.

- BRASIL. Law 9.605/1998 in Vade Mecum (São Paulo 2016) 1447-1454.

- BRÜGGER, P. Educação ou adestramento ambiental? (Chapecó; Florianópolis 2004) 165.

- DELABARY, B. Aspectos que influenciam os maus tratos contra animais no meio urbano in Revista Eletrônica em Gestão, Educação e Tecnologia Ambiental. 5 (2012) 835-840. Web Page: https://periodicos.ufsm.br/reget/article/viewFile/4245/2813 [last visited: March 10, 2019].

- FELIPE, S. Antropocentrismo, sencientismo e biocentrismo: perspectivas éticas abolicionistas, bem-estaristas e conservadoras e o estatuto de animais não-humanos in Páginas de Filosofia. 1 (2009) 2-30. Web Page: https://www.metodista.br/revistas/revistasims/index.php/PF/article/view/864/1168 [last visited: 12 fev. 2019].

- FLYNN, C. A Sociological Analysis of Animal Abuse in The International Handbook of Animal Abuse and Cruelty: Theory, Research, and Application (West Lafayette 2008) 155-174.

- FLYNN, C. Understanding Animal Abuse (New York 2012). Kindle Edition. GRAHAM, H. - MCNEILL, F. Desistência: prevendo futuros in Criminologias alternativas (Porto Alegre 2017). 573-593.

- GULlONE, E. - CLARKE, J. Animal Abuse, Cruelty, and Welfare: An Australian Perspective in The International Handbook of Animal Abuse and Cruelty: Theory, Research, and Application (West Lafayette 2008) 305-334.

- HARC. Health Implications of Animal Hoarding in Health \& Social Work. 27 (May 2002) 125-136. Web Page: http://search.proquest.com/docview/210548261?pq-origsite=qscholar [last visited: May 23, 2019].

- LEVAI, L. Direito dos animais (Campos do Jordão 2004) 48.

- MAIA, A. - BUAINAIN, A. O novo mapa da população rural brasileira in Confins. 25 (2015). Web Page: https://confins.revues.org/10548?lang=pt [last visited: May 23, 2019].

- NASSARO, M. Aplicação da teoria do link - maus tratos contra os animais e violência contra pessoas - nas ocorrências atendidas pela Polícia Militar do Estado de São Paulo (São Paulo 2013).

- PATRONEK, G. Hoarding of Animals: An Under-recognized Public health Problem in a Difficultto-study Population in Public Health Reports. 1 (1999) 81-87. Web Page: https://www.ncbi.nlm.nih.gov/pmc/articles/PMC1308348/pdf/pubhealthrep00029-0083.pdf [last visited: May 23, 2019].

- RYDER, R. Speciesism, Painism and Happiness: A Morality for the Twenty-first Century (Exeter, UK 2011).

- SOLOT, D. Untangling the Animal Abuse web in Society and Animals. 5 (1997) 257-265. Web Page: http://www.animalsandsociety.org/wp-content/uploads/2015/10/solot.pdf [last visited: May 27, 2019].

- STEKeTEE, G. et al. Characteristics and Antecedents of People who Hoard Animals: An Exploratory Comparative Interview Study in Review of General Psychology 15 (2011) 114-124.

- SUTHERLAND, E. - CRESSEY, D. Principles of Criminology (Philadelphia 1960) 3. 


\section{APPENDIX \\ QUESTIONNAIRE ON ANIMAL ABUSE}

1- How long have you been in the profession?

$\begin{array}{ll}\text { ( ) Less than } 01 \text { year } & \text { ( ) From } 01 \text { to } 05 \text { years } \\ \text { ( ) From } 05 \text { to } 10 \text { years } & \text { ( ) More than } 10 \text { years }\end{array}$

2- You develop your activities in which zone?

( ) urban ( ) rural ( ) urban and rural

3- Have you ever dealt with cases of animal abuse?

( ) Yes ( ) No. Note: In this case, please go directly to question 15.

4- How many cases of abuse have you seen as a Veterinarian (approximately)?

$\begin{array}{llll}\text { ( ) from } 01 \text { to } 05 & \text { ( ) from } 06 \text { to } 10 & \text { ( ) from } 11 \text { to } 20 & \text { ( ) More than } 20\end{array}$

5- The greatest number of cases came up when you worked (or still work) in:

( ) Clinic/Hospital ( ) NGO ( ) Zoonosis Center ( ) Slaughterhouses

( ) other. Which one?

6- The animals that were victims of abuse were predominantly:
( ) stray
( ) domiciled
( ) animals for slaughter

7- The animals that were victims of abuse were predominantly:
( ) wild
( ) wild, but domiciled
( ) exotic
( ) exotic, but domiciled
( ) domestic
( ) domesticated (ruminants, horses, pigs, birds, among others)

8- The most numerous cases of abuse that came to you can be classified as (more than one alternative can be checked):
( ) beatings
( ) burns
( ) poisonings
( ) hanging/choking
( ) weapon wounds (firearms or melee weapons)
( ) use in religious or "black magic" rituals
( ) quarrels or competitions
( ) deprivation of water and food
( ) deprivation of veterinary care
( ) confinement/chaining in a degrading situation ( ) rape
( ) forced and continuous breeding
( ) injured draft animals
( ) animal hoarding ( ) other (s). Which one?

Obs.: questions 09 to 12 refer to the profile of the abuse agent. If you don't know the authorship of the abuses, please go directly to question 13 .

9- In cases where you knew the authorship of the abuse, it can be said that the age of the offender was predominantly:
( ) under 10 years old
( ) between 10 and 20 years old
( ) between 20 and 40 years old
( ) over 40 years old

10- In cases where you knew the authorship of the abuse, it can be said that the offender, predominantly, belonged to which gender?
( ) male
( ) female

11- In the situation(s) of abuse, in which you knew that the agent was male, the cases can be classified as (more than one alternative can be checked):
( ) beatings
( ) burns
( ) poisonings
( ) hanging/choking 
( ) weapon wounds (firearms or melee weapons)

( ) use in religious or "black magic" rituals ( ) quarrels or competitions

( ) deprivation of water and food ( ) deprivation of veterinary care

( ) confinement/chaining in a degrading situation ( ) rape

( ) forced and continuous breeding

( ) injured draft animals

( ) animal hoarding ( ) other (s). Which one?

12- In the situation(s) of abuse, in which you knew that the agent was female, the cases can be classified as (more than one alternative can be checked):
( ) beatings
( ) burns
( ) poisonings
( ) hanging/choking
( ) weapon wounds (firearms or melee weapons)
( ) use in religious or "black magic" rituals
( ) deprivation of water and food
( ) quarrels or competitions
( ) confinement/chaining in a degrading situation
( ) deprivation of veterinary care
( ) forced and continuous breeding
( ) injured draft animals
( ) animal hoarding ( ) other (s). Which one?

13- If you know the reasons that led the offender(s) to attack the animal(s) that was/were attended, please check one or more alternatives:

( ) the animal was "disobedient"

( ) the animal bit or threatened the offender or a family member

( ) family fight, with aggression against people and animals

( ) the animal belonged to an enemy of the offender

( ) the offender was an alcoholic or addicted to drugs

( ) the author suffers from mental disorder

( ) negligence or ignorance about the welfare of the animal

( ) I don't know the reasons ( ) Other. Which one?

14- Did you report the case(s) of abuse?

( ) Yes, and measures have been taken by the competent departments

( ) Yes, but there was no action in relation to the case(s)

( ) Yes, but I don't know the outcome of the case(s)

( ) No

15- Would you like to make a comment or give a statement about situations of abuse, types of violence, animal and agent profiles, consequences of cases or other issues? 